\title{
Microbiological flora of cell phones: a reservoir of potential pathogens?
}

\author{
Sharma $K^{1}$, Najotra D.K $K^{2}$, Slathia $P^{3}$, Raina $S^{4}$ \\ ${ }^{1}$ Dr. Kanishtha Sharma, Senior Resident, ${ }^{2}$ Dr. Dipender Kaur Najotra, Assistant Professor, ${ }^{3}$ Mrs. Poonam Slathia, \\ Assistant Professor, ${ }^{4}$ Mrs. Shivani Raina, Assistant Professor, all authors are attached with Department of Microbiology, \\ Acharya Shri Chander College of Medical Sciences and Hospital, Jammu, Jammu and Kashmir, India.
}

Address for Correspondence: Dr. Dipender Kaur Najotra, 207- D Uttam Nagar, Kunjwani Bye Pass Jammu, J\&K. Email address: kaurdipender@gmail.com

\begin{abstract}
Background: Hospital associated infections are a major problem in all hospital settings. The heavy use of cell phones which come in close contact with the body surfaces could act as a fomite for microorganisms and it can transmit pathogenic as well as non pathogenic microorganisms. Objective: To determine the rate of bacterial contamination of cell phones of hospital staff and to study their antibiogram. Methods: A cross-sectional study was conducted in a tertiary care hospital. Sterile swabs were collected from cell phone surfaces of healthcare workers (HCW). The samples were processed as per standard microbiological techniques and antimicrobial susceptibility testing was done. Results: Out of the 100 cell phones studied, 60(60\%) showed bacterial growth. 28(56\%) were from doctors and 32(64\%) from the paramedical staff. Staphylococcus aureus with 37(55.23\%) isolates was predominant followed by CONS 12 (17.93\%), Pseudomonas sp. 7(10.44\%), E. coli 4(5.97\%) and Klebsiella pneumoniae 3(4.47\%), 2(2.98\%) Acinetobacter sp and Bacillus sp. 36 of HCW had cleaned their cell phones out of which 16 (44.44\%) showed bacterial growth whereas 64 cell phones had never been cleaned, out of which 44 (68.75\%) showed bacterial growth. Among the Gram positive isolates, Linezolid and Vancomycin were the most effective antibiotics and Imipenem and Piperacillin-Tazobactam were most effective against Gram negative isolates. Conclusion: HCW are exposed to pathogenic microorganisms which can be easily transferred to their cell phones thus acting as a source of infection to others. Cleaning of cellphones with alcohol based disinfectants and frequent hand washing should be encouraged.
\end{abstract}

Keywords: Cell phone, Fomite, Health associated infections, Healthcare workers

\section{Introduction}

Hospital associated infections (HAI) are a major problem in all hospital settings contributing significantly to morbidity and mortality of patients. A large number of items used in hospital like stethoscopes, patient's file, bronchoscopes and ballpoint pens have been reported as exogenous source of infection transferring potentially pathogenic microorganisms [1]. The majority of HAI are inadvertently transmitted through hands of health care workers (HCW) who are also integral part of current era of cell phones. Its use often occurs in a hospital for immediate communication during emergencies, in

Manuscript received: $5^{\text {th }}$ February 2017

Reviewed: $14^{\text {th }}$ February 2017

Author Corrected: $20^{\text {th }}$ February 2017

Accepted for Publication: $28^{\text {th }}$ February 2017 rounds, and even in operation theatres and intensive care units [2,3]. The cell phones make the health care delivery more efficient by increasing the speed of communication and contact within institutions. However the key concern regarding the heavy use of cell phones is that they come in close contact with the body surfaces and can act as a vector of pathogenic as well as non pathogenic microorganisms [4].

They are kept cosy and warm in our pockets and bags and act as an ideal breeding ground for the microbes [3]. No study has been carried out in our state to assess the contamination of cell phone of the HCW's, so the present study was undertaken in our hospital as a part of hospital infection control programme. 


\section{Material and Methods}

Study design, setting and participants: A crosssectional study was conducted in the Department of Microbiology of Acharya Shri Chander College of Medical Sciences and Hospital, Jammu in the month of October, 2016. The study was approved by Institutional Ethical Committee. After taking informed consent, a total of 100 random samples were taken from mobile phones of hospital staff. The sample size (n) was calculated by taking prevalence of bacterial contamination of mobile phones of health care workers as $74 \%$ based on various studies from across the country $[1,3,4]$. The allowance of error $(\mathrm{E})$ was taken as $15 \%$ of prevalence rate at $5 \%$ level of significance. Contingency for the unknown circumstance was $10 \%$.

$$
\mathrm{n}=\frac{(\mathrm{Z} \alpha / 2)^{2} \times \mathrm{P}(1-\mathrm{P})}{\mathrm{E}^{2}}=\frac{(1.96)^{2} \times 74(26)}{(10.80)^{2}}=64+10 \%=71
$$

For the convenience of calculations and comparisons 100 samples were taken.

Inclusion criteria: All doctors (Interns, Junior residents, Senior residents and consultants), nurses and other para-medical staff working in the hospital emergency and OPDs at the time of sample collection. There was no age limit and gender bias for the study.
Exclusion criteria: Any person who had participated in the study once and those who did not own a mobile phone.

Collection of samples: Under all aseptic precautions, sterile swab moistened with peptone water were rubbed on various surfaces of the cell phones. The swabs were placed in properly labelled sterile test tubes.

Sample processing: The swabs were immediately brought to the Bacteriology laboratory for processing and were inoculated on to Blood agar and MacConkey agar. The plates were incubated overnight at $37^{\circ} \mathrm{C}$ aerobically. All plates were examined for visible growth. The colonies were identified as per standard microbiological procedure. Antibiotic sensitivity testing of the microorganisms was done by modified Kirby Bauer Disc Diffusion method on Muller Hinton agar and the results were interpreted as was recommended by the CLSI (Clinical Laboratory Standards Institute) guidelines $[5,6]$.

Data management and statistical analysis: Statistical Package for Social Science (SPSS) Software, version 16 was used for data analysis. Chi-square test was performed to obtain the correlations between variables.

\section{Results}

Out of 100 cell phones screened in the study, 60(60\%) showed bacterial growth. Of these positive samples, 28(56\%) were from doctors and $32(64 \%)$ from the paramedical staff. 67 isolates were obtained from 60 culture positive samples i.e. 54(90\%) yielded single bacterial isolate, 5(8.33\%) yielded two bacterial isolates and 1(1.67\%) gave 3 bacterial isolates.

Staphylococcus aureus with 37(55.23\%) isolates was predominant followed by CONS 12(17.93\%), Pseudomonas sp. 7(10.44\%), E.coli 4(5.97\%) and Klebsiella pneumoniae 3(4.47\%). Also 2(2.98\%) isolates each of Acinetobacter sp and Bacillus sp. were obtained [Table 1] $\left(\mathrm{x}^{2}=99.51, \mathrm{p}=0.0001\right.$ significant $)$.

Table 1: Percentage distribution of isolates.

\begin{tabular}{|c|c|}
\hline Organism & No. of isolates (\%) \\
\hline S.aureus & $37(55.23 \%)$ \\
\hline CONS & $12(17.93 \%)$ \\
\hline Pseudomonas sp. & $7(10.44 \%)$ \\
\hline E.coli & $4(5.97 \%)$ \\
\hline K.pneumoniae & $3(4.47 \%)$ \\
\hline Acinetobacter sp. & $2(2.98 \%)$ \\
\hline Bacillus sp. & $2(2.98 \%)$ \\
\hline Total & $\mathbf{6 7 ( 1 0 0 \% )}$ \\
\hline
\end{tabular}


The cell phones operating with conventional keypads were found more contaminated than those with a touch screen. Fifteen of the HCWs used cell phones with conventional keypads out of which 11 (73.33\%) were contaminated whereas 85 used touch screen phones out of which 49 (57.64\%) were contaminated. Highest growth rate was obtained from mobile phones held in hands of HCWs as compared to those kept in pockets and bags. Bacterial growth was seen in $72.22 \%(26 / 36)$ of the cell phones kept in hands followed by 54.34\% (25/46) devices kept in pockets and 50\% (9/18) devices kept in bag. $\left(x^{2}=3.6, p=0.165\right.$ non-significant $)$.

36 of health professionals had occasionally or regularly cleaned their cell phones out of which $16(44.44 \%)$ showed bacterial growth whereas 64 cell phones had never been cleaned, out of which $44(68.75 \%)$ showed bacterial growth [Fig 2] $\left(\mathrm{x}^{2}=5.67, \mathrm{p}=0.0172\right.$ significant $)$.

Table 2: Correlation of disinfection and contamination.

\begin{tabular}{|c|c|c|}
\hline Status of disinfection & Contaminated & \% age of contamination \\
\hline $\begin{array}{c}\text { Disinfected } \\
\mathrm{N}=36\end{array}$ & 16 & 64.44 \\
\hline $\begin{array}{c}\text { Not disinfected } \\
\mathrm{N}=64\end{array}$ & 44 & 68.75 \\
\hline \multicolumn{2}{|c|}{$\mathrm{x}^{2}=5.67, \mathrm{p}=0.0172$ significant } \\
\hline
\end{tabular}

As far as antibiogram of bacteria is concerned, gram positive isolates showed $100 \%$ sensitivity to Linezolid and only 1 isolate of Staphylococcus aureus was found resistant to Vancomycin. The other antibiotics which were found effective were Gentamicin, Cefoxitin and Clindamycin [Table3]. Amongst the Gram negative isolates, Imipenem was the most effective antibiotic with Escherichia coli and Acinetobacter species showing $100 \%$ sensitivity followed by Piperacillintazobactam [Table 4].

Table-3: Antibiotic Sensitivity Profile of Gram Positive Isolates (N=49)

\begin{tabular}{|c|c|c|c|c|c|c|c|c|c|c|}
\hline & CD & CX & P & COT & LZ & TET & VA & C & CIP & GEN \\
\hline $\begin{array}{c}\text { S. aureus } \\
(\mathrm{N}=37)\end{array}$ & 27 & 28 & 8 & 16 & 37 & 24 & 36 & 20 & 21 & 31 \\
$(73 \%)$ & $(75.7 \%)$ & $(21.6 \%)$ & $(43.2 \%)$ & $(100 \%)$ & $(64.9 \%)$ & $(97.3 \%)$ & $(54.1 \%)$ & $(56.8 \%)$ & $(83.8 \%)$ \\
\hline $\begin{array}{c}\text { CONS } \\
(\mathrm{N}=12)\end{array}$ & 8 & 9 & 2 & 4 & 12 & 6 & 12 & 7 & 6 & 8 \\
$(66.7 \%)$ & $(75 \%)$ & $(16.7 \%)$ & $(33.3 \%)$ & $(100 \%)$ & $(50 \%)$ & $(100 \%)$ & $(58.3 \%)$ & $(50 \%)$ & $(66.7 \%)$ \\
\hline
\end{tabular}

$\mathrm{CD}=$ Clindamycin, $\mathrm{CX}=$ Cefoxitin, $\mathrm{P}=$ Penicillin, $\mathrm{COT}=$ Co-trimoxazole, $\mathrm{LZ}=$ Linezolid, $\mathrm{TET}=\mathrm{Tetracycline}, \mathrm{VA}=$ Vancomycin, $\mathrm{C}=$ Chloramphenicol, $\mathrm{CIP}=$ Ciprofloxacin, $\mathrm{GEN}=$ Gentamicin

Table-4: Antibiotic Sensitivity Profile of Gram Negative Isolates ( $=16)$

\begin{tabular}{|c|c|c|c|c|c|c|c|c|c|c|}
\hline & GEN & AK & IM & PIT & CIP & COT & CEF & CTR & CPM & AMC \\
\hline $\begin{array}{c}\text { Pseudomonas } \\
\text { sp. (N=7) }\end{array}$ & 3 & 4 & 6 & 5 & 3 & 2 & 3 & 2 & 2 & 1 \\
$(42.9 \%)$ & $(57.1 \%)$ & $(85.7 \%)$ & $(71.4 \%)$ & $(42.9 \%)$ & $(28.6 \%)$ & $(42.9 \%)$ & $(28.6 \%)$ & $(28.6 \%)$ & $(14.3 \%)$ \\
\hline $\begin{array}{c}\text { E.coli }(\mathrm{N}=4) \\
(50 \%)\end{array}$ & 3 & 4 & 3 & 1 & 1 & 1 & 1 & 1 & 1 \\
$(75 \%)$ & $(100 \%)$ & $(75 \%)$ & $(25 \%)$ & $(25 \%)$ & $(25 \%)$ & $(25 \%)$ & $(50 \%)$ & $(25 \%)$ \\
\hline $\begin{array}{c}\text { Klebsiella } \mathrm{sp} \\
(\mathrm{N}=3)\end{array}$ & 2 & 2 & 2 & 2 & 1 & 1 & 1 & 1 & 0 & 0 \\
$(66.7 \%)$ & $(66.7 \%)$ & $(66.7 \%)$ & $(66.7 \%)$ & $(33.3 \%)$ & $(33.3 \%)$ & $(33.3 \%)$ & $(33.3 \%)$ & $(0 \%)$ & $(0 \%)$ \\
\hline $\begin{array}{c}\text { Acinetobacter } \\
\text { sp. (N=2) }\end{array}$ & 1 & 1 & 2 & 1 & 1 & 1 & 1 & 1 & 1 & 0 \\
$(50 \%)$ & $(66.7 \%)$ & $(100 \%)$ & $(66.7 \%)$ & $(50 \%)$ & $(50 \%)$ & $(50 \%)$ & $(50 \%)$ & $(50 \%)$ & $(0 \%)$ \\
\hline
\end{tabular}

GEN= Gentamycin, AK= Amikacin, IM= Imipenem, PIT= Piperacillin- Tazobactam, CIP= Ciprofloxacin, COT= Cotrimoxazole, $\mathrm{CEF}=$ Ceftazidime, $\mathrm{CTR}=$ Cefriaxone, $\mathrm{CPM}=$ Cefepime, $\mathrm{AMC}=$ Amoxicillin- clavulanic acid. 


\section{Discussion}

All over the world maintaining hygiene standards is a prerequisite in all hospital settings. Excessive usage of mobile phone in the hospital by healthcare professionals has emerged as a matter of valid concern in recent years. It is due to its threat to act as a source of potential pathogens. In the present study, a total of 100 mobile phones were analysed for the presence of microorganisms out of which $60(60 \%)$ showed bacterial growth which was in accordance with Killic $\mathrm{IH}$ et al $(61.3 \%)$ and Datta P et al (72\%) $[7,8]$ while studies conducted by Karabay et al, Ulger F et al found higher rate of bacterial growth i.e. 90.98\%, 94.5\% respectively $[9,10]$.

The disparity in rate of contamination may be due to variation in the hand hygiene practises, frequency of the use and disinfection of cell phones among HCWs in various hospitals.

Results from this study showed that $56 \%$ doctors and $64 \%$ paramedical staff had bacterial contamination of their cell phones. This is in concordance with Trivedi HR et al, and Tambe NN et al $[2,12]$. Higher rate of contamination among paramedical staff may be due to their direct exposure to body fluids, tissues etc. harbouring various pathogenic organisms and lower level of awareness about the hand hygiene practises.

Among the Gram positive isolates Staphylococcus aureus $(55.22 \%)$ and CONS (17.91\%) were the predominant bacteria from the surface of cell phones as in other studies $[12,13]$. Their high occurrence rate could be traced to the fact that they are abundant in human body especially as the normal flora of the skin. Pseudomonas species (10.44\%), was the major gram negative isolate. In comparison to this Pandey A et al and Karabay $\mathrm{O}$ et al reported lower isolation of Pseudomonas species from mobile phones ie. $3.6 \%$ and $2.7 \%$ respectively $[14,9]$. It is a well known fact that Pseudomonas is an important cause of HAIs proven to remain viable for months on inanimate surfaces, disinfectants and even in distilled water which contributes to its ecologic success [15].

In our study conventional key pads showed higher rate of contamination then touch screen phones. Similar results were obtained from Pal $\mathrm{K}$ et al [4]. This might be due to the possibility of retention of more bacteria in cracks and crevices of the conventional keypads.
High isolation was obtained from mobile phones kept in hands as compared to pockets and bags. Combination of constant handling and heat generated during receiving phone call might facilitate the survival and growth of the microorganisms on the cell phone surface.

Antibiotic sensitivity pattern of Gram positive isolates revealed good sensitivity against Vancomycin and Linezolid [16]. 3 (25\%) Coagulase negative staphylococcus and 9 (24.32\%) Staphylococcus aureus were methicillin resistant. Most of the gram negative isolates were multidrug resistant [17]. Imipenem and Piperacillin- tazobactam were most effective antibiotics against them.

\section{Conclusion}

Our study concludes that healthcare workers are exposed to pathogenic microorganisms which can be easily transferred to their cell phones thus acting as a source of infection to others. Many of them lack this knowledge and thus the need for creating awareness and ensuring hygienic practices in the handling of cellphones is required. Complete restriction on the use of cell phones in the hospital is not a practical solution to the problem but still there should be restrained use in high risk areas of the hospital like ICU's and OT's. Also periodic cleaning of cellphones with alcohol based disinfectants and frequent handwashing practises should be encouraged so as to minimise transmission of HAIs.

\section{Funding: Nil, Conflict of interest: None.} Permission of IRB: Yes

\section{References}

1. Chawla K, Mukhopadhayay C, Gurung B, Bhate P, Bairy I. Bacterial 'Cell' Phones: Do cell phones carry potential pathogens? Online J Health Allied Scs. 2009 May; 8(1):8.

2. Trivedi HR, Desai KJ, Trivedi LP, Malek SS, Javdekar TB. Role of Mobile Phone in Spreading Hospital Acquired Infection: A Study in Different Group of Health Care Workers. Natl J Integ Res Med. 2011;2(3):61- 65

3. Bhat SS, Hegde SK, Salian S. Potential of Mobile Phones to Serve as a Reservoir in Spread of Nosocomial Pathogens. Online J Health Allied Scs. 2011 Jul; 10 (2):14. 
4. Pal K, Chatterjee M, Sen P, Adhya S. Contaminated Cell Phones of Health Care Personnel. National Journal of Laboratory Medicine. 2015 Oct; 4(4):33-8. DOI: NJLM/2015/13984:2069.

5. Collee JG, Miles RS, Watt B. Tests for the identification of bacteria. In: Collee JG, Fraser AG, Marmion BP, Simmons A, editors. Mackie \& McCartney Practical Medical Microbiology. 14th ed. Edinburg: Churchill Livingstone; 1996. p. 131-50.

6. CLSI. Performance standards for antimicrobial susceptibility testing. 20th Informational Supplement. M100-S20. Wayne, PA: Clinical and Laboratory Standards Institute; 2010.

7. Killic IH, Ozaslan M, Karagoz ID,Zer Y, Davutoglu $\mathrm{V}$. The microbial contamination of mobile phones used by healthcare staff. Pakistan Journal of Biological Sciences. 2009; 12(2):882-4.

8. Datta P, Rani H, Chander J, Gupta V. Bacterial contamination of mobile phones of health care workers. Indian J Med Microbiol. 2009 Jul-Sep;27(3):279-81. doi: $10.4103 / 0255-0857.53222$.

9. Karabay O, Kocoglu E and Tahtaci M. The role of mobile phones in the spread of bacteria associated with nosocomial infections. $\mathrm{J}$ Infect Developing Countries. 2007; 1(1):72-3.

10. Ulger F, Esen S, Dilek A, Yanik K, Gunaydin M, Leblebicioglu $\mathrm{H}$. Are we aware how contaminated our mobile phones with nosocomial pathogens? Ann Clin Microbiol Antimicrob. 2009 Mar 6;8:7. doi: 10.1186/1476-0711-8-7.
11. Tambe NN, Pai C. A Study of microbial flora and mrsa harboured by mobile phones of health care personnel. International Journal of Recent Trends in Science and Technology. 2012; 4(1):14-8.

12. Jayalakshmi J, Appalaraju B, Usha S. Cellphones as reservoirs of nosocomial pathogens. J Assoc Physicians India. 2008 May;56:388-9.

13. Singh S, Acharya S, Bhat M, Rao SK, Pentapati KC. Mobile phone hygiene: potential risks posed by use in the clinics of an Indian dental school. J Dent Educ. 2010 Oct;74(10):1153-8.

14. Pandey A, Asthana AK, Tiwari R, Kumar L, Das A, Madan M. Physician accessories: doctor, what you carry is every patient's worry? Indian $\mathbf{J}$ Pathol Microbiol. 2010 Oct-Dec;53(4):711-3. doi: 10.4103/ 0377-4929.72047.

15. Kramer A, Schwebke I, Kampf G. How long do nosocomial pathogens persist on inanimate surfaces? A systematic review. BMC Infect Dis. 2006 Aug 16; $6: 130$.

16. Nirupa S, Vignesh RNB, Jeya M. Can mobile phones act as vehicles transmitting nosocomial infections?. Int J Pharm Bio Sci. 2013; 4(1): $859-64$.

17. Panchal CA, Kamothi MN, Mehta SJ. Bacteriological profile of cell phones of healthcare workers at tertiary care hospital. Journal of Evolution of Medical and Dental Sciences. 2012; 1(3): 198-202.

\section{How to cite this article?}

Sharma K, Najotra D.K, Slathia P, Raina S.Microbiological flora of cell phones: a reservoir of potential pathogens?. Int J Med Res Rev 2017;5(02):204-208 doi:10.17511/ijmrr. 2017.i02.16. 